\title{
PERAN MEDIA SOSIAL "FACEBOOK” DALAM PROSES PEMBENTUKAN OPINI PUBLIK MENJELANG PEMILIHAN UMUM LEGISLATIF 2019 DI KABUPATEN ACEH JAYA
}

\author{
Aminah \\ Fakultas Ilmu Sosial dan Ilmu Politik, Universitas Teuku Umar \\ aminah@utu.ac.id
}

\begin{abstract}
This research aims to explain about to examine about the role of social media in making public decisions ahead of the legislative election 2019 in the district of Aceh Jaya. The data that is required in writing is obtained through library research and field. Library research done with how to read text books, legislation, and other reading material related to this research. While field research done by interviewing informants. The results of the study showed that the process of forming public opinion cannot be formed by itself. The process of forming public opinion consists of several stages, namely Phase I which is caused by several factors: cultural background, past, espoused values and news that develops. Stage 2 the formation of perception in the community, the third stage is formed, the fourth stage is the consensus, namely the last and last process or agreement on a public opinion. Through Facebook media, the process of forming public opinion is very fast. This happens to the maximum extent possible for people who use social media
\end{abstract}

Keywords: The Role, media, public opinion and Legislative Election

\section{A. PENDAHULUAN}

Internet merupakan suatu hal yang tidak dapat dipisahkan lagi bagi kehidupan masyarakat, baik di wilayah perkotaan maupun di wilayah pedesaan. Seiring dengan berkembangnya teknologi informasi komunikasi yang semakin pesat, internet telah masuk dan merambah kedalam kehidupan umat manusia. Perkembangan zaman menuntut manusia untuk memanfaatkan kemajuan tekhnologi dalam berkomunikasi. Komunikasi terjadi karena adanya pesan yang disampaikan oleh komunikator (Penyampai pesan) kepada komunikan (penerima pesan) yang kemudian dilanjut dengan adanya feedback dari komunikan sebagai timbal balik dari pesan komunikator yang menimbulkan efek. Seiring berjalannya waktu serta kemajuan tekhnologi yang semakin canggih maka komunikasi akan mudah dilakukan oleh setiap insan. Belakangan ini muncul berbagai macam sosial media seiring dengan kemajuan tekhnologi seperti Facebook, Twitter, Blackberry Messanger, WhatsApp Path, Instragam dan lain-lain. Kemunculan berbagai macam aplikasi sosial media ini kemudian dimanfaatkan oleh banyak orang untuk berkomonikasi yang berkepintangan dalam membentuk opini publik.

Maraknya perkembangan sosial media ini dapat dimanfaatkan oleh Para komunikator untuk kepentingan tertentu seperti mempromosikan barang dagangan, perbaikan citra seseorang atau hal lain. Kehadiran media sosial juga mempengaruhi bidang politik. Studi di Amerika Serikat 
menunjukkan media sosial alat kampanye yang efektif. Sebelum era media sosial, politisi di Negeri Paman Sam sudah memanfaatkan internet untuk media berkampanye. (Chavez, 2012; Stietglitz \& Dang Xuan,2012). Tidak dapat dipungkiri bahwa dalam kurun waktu yang singkat dan sangat cepat setiap komunikan akan mudah menguasai bagaimana cara menggunakan sosial media yang sudah ada, maka para komunikan pun akan lebih mudah mendapatkan pesan lalu mereka akan mengeluarkan pendapat ataupun opini masing-masing.

Setiap individu memiliki persepsi atau pendapat masing-masing mengenai isi pesan (isu) yang disampaikan oleh komunikator, namun kebiasaannya setiap individu komunikan akan membahas isu yang sama disaat merkea memiliki waktu untuk mengeluarkan pedapat dan berdiskusi mengenai isu tersebut, maka dari hasil diskusi itu terbentuklah sebuah opini publik yang mewakili pendapat dari banyak individu. Sehingga untuk meyampaikan pesan tersebut para komunikator membutuhkan sebuah media agar para komunikan bisa menerima pesan yang disampaikannya. Selain itu, opini publik terjadi karena adanya pesan dari komunikator kemudian terjadilah diskusi diantara para komunikan lalu para komunikan itu mengambil sebuah sikap terhadap isi pesan yang disampaikan oleh komunikator. Pendapat para komunikan ini dapat berupa pendapat yang positif atau bahkan pendapat negatif.

Menjelang pemilihan umum legislatif (Pileg) di Kabupaten Aceh Jaya, setiap para bakal calon anggota legislatif mulai menyusun strategi ataupun cara agar dapat menjadi perhatian serta mendapatkan dukungan dari masyarakat kabupaten Aceh Jaya per daerah pemilihan (dapil)-nya. Dapil di kabupaten Aceh Jaya dibagi menjadi empat dapil yaitu Dapil 1 meliputi wilayah Kecamatan Krueng Sabee dan Panga, Dapil 2 wilayah Kecamatan Teunom dan Pasie Raya, Dapil 3 Wilayah Kecamatan Jaya dan Indra Jayasedangkan Dapil 4 meliputi wilayah Sampoiniet, Darul Hikmah dan Setia Bakti (KIP Aceh Jaya, 2018). Penentuan jumlah kursi ini diperhitungkan berdasarkan jumlah penduduk.

Opini publik dapat dibentuk dengan adanya pencitraan dari isi pesan yang disampaikan oleh komunikator, seperti isu-isu yang sering terjadi dikalangan para komunikan. Maka untuk membentuk opini publik ini, komunikator harus membuat isi pesan yang benar-benar mudah dicerna dan mudah dipahami oleh komunikan yang dituju. Sehingga antara sosial media dan opini publik dapat berjalan beriringan. Sosial media adalah sebuah media on line, dengan para penggunanya bias sehingga dengan mudah para komunikan ikut berpartisipasi. Sehingga banyak isu-isu yang beredar dimasyarakat hingga membentuk sebuah opini publik.

Menjelang pemilihan umum legislatif 2019, berbagai macam cara mulai dilakukan oleh setiap Para bakal calon anggota legislatif baik dilakukan oleh partai politik maupun dilakukan oleh Para bakal calon itu sendiri. Salah satu cara yang ditempuh oleh para bakal calon anggota legislatif yaitu dengan memanfaatkan media sosial terutama Facebook yang digunakan sehari-hari oleh setiap lapisan masyarakat. Mudahnya proses terbentuknya opini publik melalui media Facebook menjadikan para calon anggota legislatif berlomba-lomba untuk memanfaatkannya demi mendapatkan perhatian serta 
dukungan dari masyarakat. Berdasarkan permasalahan tersebut, penelitian ini bertujuan untuk mengkaji tentang peran media sosial "facebook" dalam proses pembentukan opini publik menjelang pemilihan umum legislatif 2019 di kabupaten Aceh Jaya.

\section{B. Kerangka Teori}

Dalam kajian ini, penulis menggunakan teori-teori yang relevan dari berbagai literatur khususnya tentang peran, Komunikasi Massa, Media Massa, Media Sosial dan Opini Publik.

\section{Pengertian Peran}

Peran merupakan aspek yang dinamis dalam kedudukan terhadap sesuatu. Apabila seseorang melakukan hak dan kewajibannya sesuai dengan kedudukannya, maka ia menjalankan suatu peran (Soeharto, 2002; Soekanto,1984: 237). Teori peran yaitu teori yang merupakan perpaduan antara teori, orientasi, maupun disiplin ilmu, selain dari psikologi, teori peran dikenal sebagai teori yang berawal dari sosiologi dan masih tetap digunakan dalam kajian sosiologi dan antropologi (Sarwono, 2002). Dalam ketiga ilmu tersebut, istilah "peran" diambil dari dunia teater. Dalam teater, seorang aktor harus bermain sebagai seorang tokoh tertentu dan dalam posisinya sebagai tokoh itu ia mengharapkan berperilaku secara tertentu.

Berikut adalah berapa dimensi peran, diantaranya yaitu:

1. Peran sebagai suatu kebijakan. Pengikut paham ini berpendapat bahwa peran merupakan suatu kebijkasanaan yang tepat dan baik untuk dilaksanakan;

2. Peran sebagai strategi. Penganut paham ini mendalilkan bahwa peran merupakan strategi agar mendapatkan dukungan dari masyarakat (public supports);

3. Peran sebagai alat komunikasi. Peran didayagunakan sebagai instrumen atau alat untuk mendapatkan masukan berupa informasi dalam proses pengambilam keputusan. Persepsi ini dilandaskan oleh suatu pemikiran bahwa pemerintahan dirancang untuk melayani masyarakat, sehingga pandangan dan preferensi dari masyarakat tersebut adalah masukan yang bernilai guna mewujudkan keputusan yang responsif dan responsibel;

4. Peran sebagai alat penyelesaian sengketa, peran ini didayagunakan sebagai suatu cara agar dapat mengurangi atau meredam konflik melalui 8 usaha pencapaian konsesus dari pendapatpendapat yang ada. Asumsi yang melandasi persepsi ini adalah bertukar pandangan sehingga dapat meningkatkan pengertian dan toleransi serta dapat mengurangi rasa ketidakpercayaan dan kerancuan didalam kehidupan masyarakat;

5. Peran sebagai terapi. Menurut pendapat ini, peran yang dikukan yaitu sebagai upaya agar masalah-masalah psikologis masyarakat seperti halnya perasaan ketidakberdayaan, tidak percaya diri dan perasaan bahwa diri mereka bukan komponen penting dalam masyarakat (Horoepoetri, Arimbi dan Santosa, 2003), 
Dalam kajian ini peran yang dimaksud adalah peran peran sebagai strategi dn peran sebagai alat komunikasi. Sehingga dalam menganalisa data akan menjadikan kedua peran ini fokus pada proses pembentukan opini publik menjelang pemilihan umum legislatif 2019 di kabupaten Aceh Jaya.

\section{Komunikasi Massa}

Komunikasi massa merupakan proses dimana organisasi media membuat dan kemudian menyebarkan isi pesan yang telah dibuat kepada khalayak banyak. Organisasi-organisai tersebut akan menyebarluaskan pesan-pesan yang akan mempengaruhi dan mencerminkan kebudayaan suatu masyarakat, lalu informasi ini akan mereka hadirkan serentak pada khalayak luas yang beragam. Hal ini membuat media massa menjadi bagian dari salah satu institusi yang kuat di masyarakat. Dalam komunikasi massa, majalah, atau menampilkan teras berita yang memikat bagi sebuah kisah berita. ia adalah ilmu dalam pengertian bahwa ia meliputi prinsip-prinsip tertentu tentang bagaimana berlangsungnya komunikasi yang dapat dikukuhkan dan dipergunakan untuk membuat berbagai hal menjadi lebih baik ( Effendi, $2004: 21$ ).

Cangara menjelaskan bahwa media adalah alat atau sarana yang digunakan untuk menyampaikan pesan dari komunikator kepada khalayak, sedangkan media massa sendiri alat yang digunakan dalam penyampaian pesan dari sumber kepada khalayak dengan menggunakan alat-alat seperti surat kabar, film, televisi dan radio. Sebuah media bisa disebut media massa jika memiliki karakteristik tertentu, diantaranya:

1. Bersifat melembaga, artinya pihak yang mengelola media terdiri dari banyak orang yakni mulai pengumpulan, pengelolaan, sampai penyajian informasi.

2. Bersifat satu arah, artinya komunikasi yang dilakukan kurang memungkinkan terjadinya dialog antara pengirim dan penerima. Kalau pun terjadi reaksi atau umpa balik, biasanya memerlukan waktu dan tertunda.

3. Meluas dan serempak, artinya dapat mengatasi rintangan waktu dan jarak karena ia memiliki kecepatan. Bergerak secara luas dan simultan, dimana informasi yang disampaikan diterima oleh banyak orang dalam waktu yang sama.

4. Memakai peralatan teknis atau mekanis, seperti televisi, radio, surat kabar, dan semacamnya.

5. Bersifat terbuka, artinya pesannya dapat diterima oleh siapa saja dan dimana saja tanpa mengenal batas usia, jenis kelamin, dan suku bangsa.

Selain memiliki karakteristik sendiri, media massa juga memiliki kategori sebagai berikut:

a. Media cetak, contohnya surat kabar/Koran, majalah, buku, newsletter.

b. Media elektronik, televisi, radio, video dan film Media on line, syber media, media internet, media berbasis internet 


\section{Media Sosial}

Media sosial merupakan sebuah media online, dengan para penggunanya dapat dengan mudah berkomunikasi antara satu dengan yang lainnya serta dapat ikut berpartisipasi, berbagi dan menciptakan isi yang meliputi blog, jejaring sosial, wiki, forum dan dunia virtual. Blog, jejaring sosial dan wiki merupakan bentuk media sosial yang umum digunakan oleh masyarakat diseluruh dunia. Pendapat lain mengatakan bahwa media sosial adalah media online yang mendukung interaksi sosial dan media sosial menggunakan tekhnologi berbasis web yang mengubah komunikasi menjadi dialog interaktif.

Jejaring sosial merupakan situs dimana setiap orang bisa membuat webpage pribadi, kemudian terhubung dengan teman-teman untuk berkomunikasi serta berbagi informasi. Jejaring sosial terbesar saat ini antara lain Facebook, instagram, myspace dan twitter. Jika media tradisional menggunakan media cetak dan media broadcast, maka media sosial menggunakan internet. Media sosial mengajak siapa saja yang tertarik untuk berpartisipasi dengan membri kontribusi dan feedback secara terbuka, memberi komentar serta membagi infromasi dengan waktu yang cepat dan tak terbatas.

Saat teknologi internet dan mobile phone makin maju maka pengguna media sosial pun ikut tumbuh secara pesat. Kini untuk mengakses facebook atau instagram misalnya, dapat dilakukan dimana saja dan kapan saja hanya dengan menggunakan mobile phone. Demikian cepat orang-orang dapat mengakses media sosial yang mengakibatkan adanya fenomena besar dalam arus informasi tidak hanya di negara-negara maju, tetapi juga di Indonesia. Karena kecepatannya media sosial tampak mulai menggantikan media massa konvensional dalam menyebarkan berita-berita.

Media sosial memiliki ciri-ciri yaitu sebagai berikut:

1. Pesan yang disampaikan tidak hanya untuk satu orang saja namun bisa ke berbagai banyak orang.

2. Pesan yang disampaikan bebas, tanpa harus melalui gatekeeper.

3. Pesan yang disampaikan cenderung lebih cepat dibandingkan media lainnya.

4. Penerima pesan yang menentukkan waktu interaksi.

Selain itu, media sosial juga merupakan alat promosi yang efektif karena dapat diakses oleh siapa saja yang terhubung dengan internet, sehingga jaringan promosi bisa lebih luas. Media sosial menjadi bagian yang sangat diperlukan oleh pemasaran bagi banyak perusahaan dan kalangan terutama bagi calon anggota legislatif yang ingin maju sebagai wakil rakyat yang ingin mendekati rakyat dan Para pemilihnya. Media sosial memiliki berbagai kelebihan dibandingkan media konvensional, diantaranya yaitu:

1. Sederhana. Dalam produksi media konvensional dibutuhkan keterampilan tingkat tinggi dan keterampilan marketing yang unggul. Sedangkan pada media sosial sangat mudah digunakan, 
bahkan untuk orang tanpa dasar TI pun dapat mengaksesnya, yang dibutuhkan adalah computer dan koneksi internet.

2. Dapat membangun hubungan. Sosial media menawarkan kesempatan untuk berinteraksi dengan Para pelanggan dan membangun hubungan. Pihak komunikator mendapatkan sebuah feedback langsung, ide, pengujian dan mengelola layanan dari komunikan dengan cepat. Tidak dengan media tradisional yang tidak dapat melakukan hal tersebut, media konvensional hanya melakukan komunikasi satu arah.

3. Jangkauan Global. Media tradisional dapat menjangkau secara global tetapi tentu dengan biaya sangat mahal dan memakan waktu yang lama. Melalui media sosial dapat mengkomunikasikan informasi dalam sekejap, terlepas dari letak geografis dan sebagainya.

4. Terukur. Dengan system tracking yang mudah, pengiriman pesan dapat terukur, sehingga para komunikator dapat mengetahui efektifitas promosi yang dilakukan selama ini. Tidak demikian dengan media konvensional yang membutuhkan waktu yang lama.

\section{Opini Publik}

Opini adalah serapan dari bahasa asing (opinion), merupakan tanggapan atau jawaban terbuka terhadap sesuatu persoalan yang dinyatakan berdasarkan kata-kata, baik dalam bentuk lisan maupun tulisan. Opini juga dapat berupa prilaku, sikap tindak, pandangan dan tanggapan.

\section{Ciri-Ciri Opini}

1. selalu diketahui dari pernyataan-pernyataan;

2. merupakan sintesa dari banyak pendapat;

3. mempunyai pendukung dalam jumlah yang besar

Jika sebuah opini merupakan opini seseorang, maka tidak akan menimbulkan sebuah masalah. Namun, berbeda halnya jika opini tersebut menjadi opini publik, maka akan banyak permasalahan yang akan terjadi, karena hal ini menyangkut dan berkaitan dengan orang banyak. Dan diantara orang banyak itu akan melakukan komunikasi, guna menyampaikan pendapatnya masing-masing.

\section{Sikap Opini Publik}

1. Sikap adalah reaksi terbuka seseorang terhadap suatu peristiwa, namun tidak dimaksud untuk diperlihatkan.

2. Sikap Opini merupakan opini yang masih tersembunyi di dalam batin seseorang yang merupakan apa yang sebenarnya dirasakan oleh seseorang.

3. Menurut John H. Harvey dan William P. Smith: Sikap adalah kesiapan merespon secara konsisten dalam bentuk positif atau negatif terhadap obyek atau situasi tertentu. 


\section{Macam-macam opini:}

1. Opini yang berwujud/berisi ide/gagasan

2. Opini keyakinan/ideology

3. Opini yang berupa pemikiran

\section{Opini dibentuk berdasarkan :}

1. Kumpulan data dan fakta

2. Rekontruksi dari keadaan

3. Reaksi atau sikap individu baik sebagai komunikator maupun komunikan yang ditentukan oleh situasi komunikator maupun komunikan itu sendiri.

\section{Unsur-unsur opini:}

1. Belief (kepercayaan tentang sesuatu)

2. Attitude (apa yang sebenarnya dirasakan oleh seseorang)

3. Perception (persepsi

Adapun proses pembentukan opini publik dapat dilihat pada gambar berikut ini:
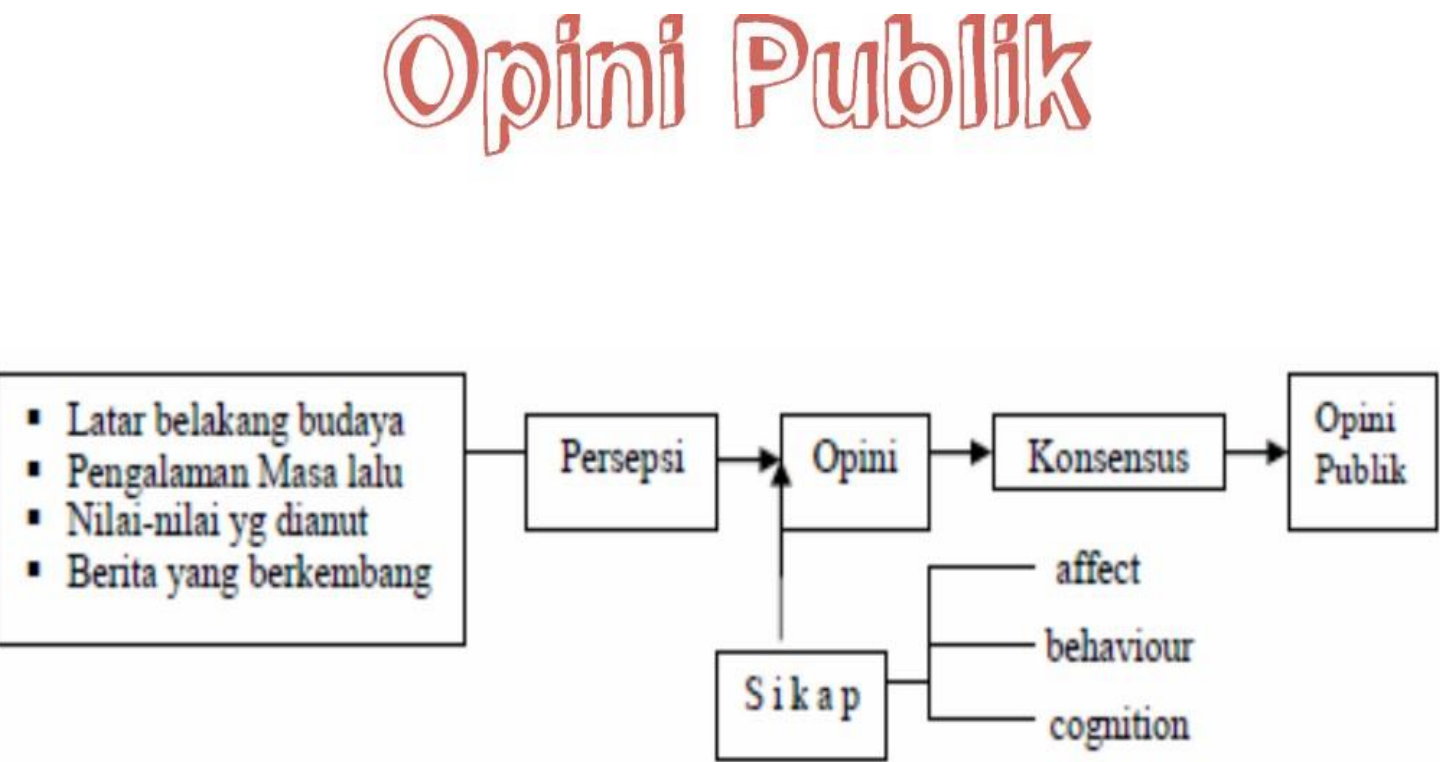

Gambar 1. Proses pembentukan opini publik

C. Metode

Metode yang digunakan dalam penelitan ini yaitu metode kualitatif deskriptif. Teknik pengumpulan data dilakukan dengan dua cara yaitu studi kepustakaan dan ke lapangan. Studi kepustakan dilakukan dengan mencari berbagai referensi yang mendukung terhadap kasus yang diangkat. Sedangkan ke lapangan dengan observasi serta melihat, memantau informasi terkait melalui 
akun media sosial "Facebook" pribadi penulis terkait peran media sosial facebook dalam proses pembentukan opini publik menjelang pemilihan umum legislatif di kabupaten Aceh Jaya.

\section{PEMBAHASAN DAN ANALISIS}

Hasil penelitian berikut menguraikan tentang bagaimana peran media facebook dalam proses pembentukan opini publik menjelang pemilihan umum legislatif 2019 di kabupaten Aceh Jaya. Tidak dapat dipungkiri bahwa perkembangan media sosial begitu pesat yang membawa pengaruh yang sangat besar dalam kehidupan manusia sehari-hari. Setiap hari dapat terupdate begitu banyak beritaberita yang berkembang serta mempengaruhi terhadap pembentukan opini publik di kalangan masyarakat Indonesia. Seperti yang diketahui bahwa seiring perkembangan zaman dan kemajuan tekhnologi informasi dan komunikasi maka informasi apapun akan sangat mudah menjangkau dan didapatkan oleh semua lapisan masyarakat (komunikan). Para komunitorpun memanfaatkan keberadaan sosial media facebook ini sebagai alat untuk menyampaikan berbagai hal informasi kepada seluruh masyarakat yang dituju. Karena dengan memanfaatkan sosisal media maka informasi yang disampaikan pun akan sampai kepada para pengguna sosial media secara serentak dan dalam waktu yang bersamaan. Hasil data yang di dapatkan dalam penelitian ini menggunakan pendekatan analisis proses pembentukan opini publik. Adapun hasil penelitian adalah sebagai berikut:

\section{Tahap I}

Proses pembentukan opini publik tahap I disebabkan oleh beberapa faktor yaitu latar belakang budaya, pengalaman masa lalu, nilai-nilai yang dianut dan berita yang berkembang. Untuk proses pembentukan opini publik di kalangan masyarakat kabupaten Aceh Jaya biasanya terbentuk sebuah opini melalui media "facebook" disebabkan oleh faktor pengalaman masa lalu dan berita yang berkembang. Pengalaman masa lalu dalam hal ini yaitu Para calon anggota legislatif yang maju pada periode 2019 ini, mencoba memunculkan ide-ide barunya melalui akun sosial medianya untuk dijadikan sebagai konsumsi publik. Para calon anggota legislatif mencoba untuk mengekspos kembali pengalaman-pengalaman masa lalu yang mungkin sudah dilupakan oleh sebagian masyarakat. Hal ini seperti yang diungkapkan oleh DZ, berikut adalah hasil wawancaranya:

"biasanya calon anggota legislatif yang maju untuk pileg ke depan ini banyak yang mencoba untuk meng-update statusnya di facebook terkait pengalaman masa lalu. Ada yang mencoba untuk menawarkan program-program yang berpihak ke masyarakat misalkan dengan meng-update beberapa foto pengabdiannya bersama masyarakat atau bahkan ada yang mencoba untuk menunjukkan tingkat kepeduliannya kepada masyarakat itu sangat tinggi" (Wawancara, 30 September 2018).

Hal yang sama juga diungkapkan oleh YD, sebagai masyarakat yang selalu aktif dalam dunia media sosial. Berikut adalah kutipan hasil wawancaranya: 
"Cuma sebenarnya banyak calon legislatif kita itu kadang cari prhatian masyarakat itu Cuma pada momen-momen yang seperti ini. Padahal kami masyarakat tidak perlu terlalu terlihat di dunia maya. Kami butuh mereka di dunia nyata. Jadi memang ada beberapa calon anggota legislatif kita itu lebih aktif di dunia maya daripada dunia nyata. Mereka mencoba update status facebooknya dengan berbagai kegiatan ang pernah mereka lakukan yang kira-kira dapat menarik perhatian masyarakat. Namun kadang justru dengan mereka update status akan berdampak negatif pada diri calon itu sendiri. Karena banyak juga yang berkomentar pedas terhadap mereka dan bahkan di iyakan oleh beberapa netizen lainnya." (Wawancara, 2 Oktober 2018).

Berdasarkan hasil wawancara diatas dapat dilihat bahwa Dengan memunculkan kembali isu yang lama mengundang pihak komentator-komentator (pengguna media facebook lainnya) untuk memberikan tanggapan hingga menjadi sebuah persepsi di kalangan masyarakat. Selain dari pengalaman masa lalu, berita yang berkembang juga sering dijadikan isu oleh pihak komunikator dalam hal ini para calon anggota legislatif 2019 di Kabupaten Aceh Jaya. Hal utama yang dilakukan oleh pihak komunikator adalah memilih topik yang akan dikembangkan untuk dijadikan sebagai suatu isu yang menarik serta mendapatkan komentar yang banyak dari Para netizen. Pemilihan berita yang tepat dan yang sedang berkembang adalah salah satu strategi yang digunakan oleh para calon anggota legislatif untuk menyamakan persepsi atau bahkan persepsi yang berbeda akan timbul dari suatu pernyataan yang ditimbulkan dari pesan yang disampaikan oleh komunikator.

\section{Tahap II}

Pada tahap ini setelah melewati proses tahap awal, persepsi adalah tahap kedua. Tahap ini memunculkan berbagai prsepsi dari sejumlah lapisan masyarakat yang berkomentar terhadap salah satu isu yang dilemparkan oleh pihak komunikator melalui media facebook tersebut. persepsi ini juga sama halnya dengan tanggapan ataupun anggapan atau bahkan komentar masyarakat yang ditumpahkan melalui kolom komentar facebook baik komentar positif maupun negatif. Dalam mengeluarkan setiap persepsi yang dilontarkan oleh setiap lapisan masyarakat akan terlihat bahwa ada berapa banyak orang yang setuju terhadap status atau isu yang dikembangkan oleh para calon anggota legislatif tersebut.

Komentar positif biasanya selalu dihiasi oleh Para pendukung caln anggota legislatif tersebut. sebaliknya, Para netizen yang tidak memberikan dukungan akan selalu membantah setiap argument yang dikeluarkan oleh pihak anggota legislatif tersebut. dalam proses pembentukan opini tersebut sangat berpengaruh terhadap elektabilitas calon anggota legislatif yang ingin mendapatkan dukungan dari seluruh lapisan masyarakat terutama diwilayah atau daerah pemilihannya. Jika salah seorang calon anggota legislatif selalu mendapatkan komentar serta tanggapan yang bersifat negatif dari masyarakat daerah pemilihannya akan sulit untuk memperoleh kursi di tingkat kabupaten Aceh Jaya. Hal ini dikarenakan setiap tanggapan yang diberikan selalu mendapat tanggapan negatif dari masyarakat otomatis akan tercipta suatu persepsi dimasyarakat bahwa calon anggota legislatif tersebut 
tidak dapat mewakili mereka untuk membawa aspirasinya selama lima tahun kedepan. Namun sebaliknya jika calon anggota legislatif yang mampu mempengaruhi persepsi masyarakat dan mampu menjadikan persepsinya sebagai persepsi masyarakat pada umumnya akan mendapatkan pengakuan bahwa masyarakat akan mempercayai bahwa calon anggota legislatif ini mampu membawa aspirasi masyarakat kedepan dan patut untuk dijadikan sebagai anggota legslatif.

Selain itu, jika calon anggota legislatif memberikan suatu isu yang memperoleh pendukung yang banyak akan terlihat bahwa ada begitu banyak yang meng-like terhadap postingan-postingan yang diisukan oleh calon anggota legislatif. Selain meng-like Para pendukung juga akan menanggapi atau bahkan membagikan status tersebut kepada grup dan lainnya sehingga semakin ramai diperbincangkan terhadap opini yang dibangunkan oleh calon legislatif. Hal ini seperti yang diungkapkan oleh AZ, berikut adalah hasil wawancaranya:

"Dari Dinding Facebook masing-masing kita bisa selalu memantau bahwa banyak sekali yang mulai melakukan pencitraan dan membagikan berbagai macam isu-isu yang sedang berkembang terutama ditingkat lokal. Biasanya akan selalu hadir Para netizen sebagai heters dan juga pendukung salah satu calon anggota legislatif tersebut. biasanya ada banyak orang yang mencoba mencari kesalahan-kesalahan yang pernah dilakukan sebelumnya oleh DPRK yang sudah pernah menjabat. Nah ini sering mendapat komentar-komentar dari berbagai lapisan masyarakat. Ada yang komentar positif ada yang komentar negatif." (Wawancara, 30 September 2018).

Hal yang sama juga diungkapkan oleh DM, sebagai salah satu masyarakat yang selalu aktif dalam dunia maya. Berikut adalah kutipan hasil wawancaranya:

"Dinding Facebook bakal calon anggota legislatif itu selalu dibanjiri oleh komentar-komentar dari masyarakat. Ada pro dan pastinya juga selalu ada yang kontra. Ada yang kadang-kadang Cuma asal-asalan ada juga beberapa calon anggota legislatif itu selalu mendapatkan respon positif dari masyarakat dan Para netizen. Nah ini sebenarnya juga sangat penting untuk meraih dukungan terbanyak dari daerah pemilihannya masing-masing sang calon." (Wawancara, 2 Oktober 2018).

Berdasarkan hasil wawancara diatas dapat dilihat bahwa masyarakat selalu memantau terhadap perkembangan atau dinding Facebook dari sang bakal calon Anggota legislatif. Namun dalam perkembangannya, setiap bahasa yang dikeluarkan oleh Para bakal calon pasti mendapatkan berbagai macam tanggapan ataupun persepsi dari berbagai kalangan masyarakat baik positif maupun negatif.

\section{Tahap III}

Tahap ke tiga yaitu terbentuknya sebuah opini. Opini dalam setiap individu dapat terbentuk melalui persepsi. Selain melalui persepsi opini juga dapat terbentuk melalui sikap yang ditunjukkan oleh seseorang. Sikap adalah kesiapan seseorang dalam merespon secara konsisten dalam bentuk positif atau negatif terhadap obyek atau situasi tertentu. Dalam hal ini sikap akan ditunjukkan oleh setiap individu yang mengikuti akun facebook sang calon anggota legislatif di daerah pemeilihannya di kabupaten Aceh Jaya. Selain itu, di akun facebook yang dapat memberikan komentar dan 
tanggapan bukan hanya dari daerah pemilihannya saja. Jika opini yang dibangun bersifat positif dan mendapat tanggapan positif dari seluruh lapisan masyarakat maka kemungkinan besar akan mampu membentuk opini positif dari masyarakat lainnya.

Opini yang terbentuk dalam setiap individu dapat berbagai macam bentuknya. Ada yang berbentuk positif ada pula dalam bentuk negatif. Ada yang menggungkapkan dan menunjukkan sikapnya ada juga hanya memendamkan di dalam hatinya saja. Akan tetapi kesemuannya tersebut adalah bentuk sikap yang ditunjukkan oleh setiap ndividu yang akan menjadi pemilih di pemilihan umum legislatif tahun 2019 mendatang.

Berdasarkan proses pembentukan opini publik, ada beberapa persepsi dan opini tidak menjadi sebuah opini publik dan hanya sampai di tahap persepsi dan opini saja. Namun ada yang sampai ke tahap opini publik. Proses untuk menjadi opini publik harus melewati satu tahap lagi yaitu tahap konsensus sehingga baru dapat dijadikan sebagai opini publik. Jika tidak melewati tahap ini maka hanya dianggap sebagai opini individu atau kelompok.

\section{Tahap IV}

Tahap ke empat ini adalah tahap terakhir menuju opini publik. Pada tahap ini harus ada konsensus yaitu kesepakatan atau persetujuan secara bersama yang dilakukan oleh beberapa orang atau kelompok. Konsensus juga dapat diartikan sebagai suatu persamaan persepsi dari satu argument atau pendapat yang dikeluarkan oleh seseorang. Pendapat seseorang dapat dikategorikan sebagai suatu opini publik apabila telah mendapatkan persetujuan dari berbagai pihak. Opini publik yang sering terbentuk melalui media facebook adalah pendapat para calon anggota legislatif yang memiliki banyak pendukung di media facebook. Pendukung yang banyak sangat dibutuhkan untuk menjadikan suatu isu sebagai sebuah opini publik. Sehingga setiap isu apapun yang dilemparkan kepada masyarakat akan menjadikannya sebagai suatu opini publik.

Ada berbagai macam opini yang beredar di masyarakat. Salah satu contoh kongkritnya ditingkat nasional adalah adanya \#2019GantiPresiden. Ini merupakan salah satu bentuk opini publik yang tercipta di dalam masyarakat nusantara. Setiap opini yang diutarakan selalu dihadirkan pro dan kontranya. Hal ini menunjukkan bahwa tidak semua orang setuju dengan opini \#2019GantiPresiden akan tetapi sebagian masyarakat Indonesia yang masih mempertahankan Jokowi sebagai presidennya juga menciptakan opini dengan \#Jokowi2Periode. Hal yang sama juga teradi tingkat daerah. Tak terkecuali di kabupaten Aceh Jaya. Para calon anggota legislatif mencoba untuk meraih dukungan dari masyarakat melalui media online yaitu Facebook. Pemanfaatan media Facebook dilakukan semaksimal mungkin oleh pihak calon-calon anggota legislatif di Kabupaten Aceh Jaya. Setiap calon mulai menciptakan opini-opini yang bersifat positif untuk dijadikan sebagai opini publik. 


\section{Tahap V}

Tahap V ini adalah tahap terakhir dapam proses pembentukan opini publik. Pada tahap ini opini publik sudah terbentuk. Opini publik tidak dapat terjadi dengan sendirinya tanpa melewati berbagai macam tahapannya. Setelah melewati beberapa proses tahapan barulah terbentuk sebuah opini. Opini yang telah terbentuk dalam masyarakat juga tidak terlepas dari berbagai macam persepsi masyarakat yang nantinya akan menimbulkan pro dan kontra terkait isu yang dikembangkan tersebut. Dalam proses pembentukan opini publik di masyarakat, Para politisi di seluruh dunia telah mengoptimalkan dan memanfaatkan media sosial untuk menjalin hubungan interaksi dengan para pemilihnya, berdialog langsung dengan masyarakat serta membentuk diskusi-diskusi politik.

Kemampuan menciptakan ruang dialog antara para politisi dengan publik serta menarik minat pemilih pemula/pemilih muda membuat media sosial semakin penting bagi politisi. Hal ini dikerankan pemilih pemula sangat terpengaruh untuk mengikuti politik yang sedang berkembang di dalam masyarakat terutama pemantauan melalui media sosial Facebook. Sebelum memanfaatkan media sosial, para politisi sudah menggunakan internet untuk berkampanye. Internet bisa menjadi cara yang potensial dalam mendobrak politik demokrasi massa yang menyuarakan suara masyarakat dari bawah ke atas, yang kerap dengan power yang dimiliki, dimanfaatkan oleh penguasa untuk kepentingan golongannya. Internet diharapkan bisa menjadi media bagi mengalirnya informasi dua arah yang saling interaktif antara politisi dan pendukungnya. Sehingga melalui media sosial tersebut, masyarakat dapat menyampaikan aspirasinya kepada pihak-pihak terkait termasuk kepada orang yang mewakili mereka.

Internet menjanjikan memberikan forum yang seluas-luasnya bagi pengembangan kelompok kepentingan dan sebagai sarana penyaluran opini (Asih, 2011). Penggunaan media sosial dianggap lebih efiktif dan lebih efisien dari pada penggunaan sarana lainnya seperti pemasangan baliho, iklan di Koran, pembagian kartu identitas dan lainnya. Hal ini seperti yang diungkapkan oleh TZ sebagai salah satu calon anggota legislatif di Kabupaten Aceh Jaya dapil 1 kecamatan Panga dan kecamatan Krueg Sabee, berikut adalah hasil wawancaranya:

"Media Facebook sangat efektif kita gunakan sebagai media untuk mengambil hati masyarakat, terutama untuk kalangan Para remaja atau pemilih pemula. Mereka kan sangat aktif dalam menggunakan media sosial terutama Facebook dan WhatsApp. Jadi manfaatnya sangat besar selain bisa menjaring pemilih di dapil kita, kita juga bisa ajak untuk berdiskusi bersama dalam suatu forum media sosial tersebut. ini sangat efektif selain tidak harus jumpa secara langsung juga dapat menghemat untuk biaya kampanye. Jadi kita tidak perlu juga untuk mengumpulkan massa untuk melakukan diskusi secara langsung. Yang tentunya mengganggu aktivitas sehari-hari masyarakat kita. Selain itu, mereka juga bisa menyampaikan aspirasinya melalui akun tersebut. nah disini tentunya sangat penting. Karena terkadang masyarakat kita banyak yang tidak mau berbicara secara terus terang tentang kondisi atau aspirasi yang mau disampaikan masing-masing kelompok. Jadi melalui media sosial mereka bisa mengutarakannya." (Wawancara, 30 September 2018). 
Hal yang sama juga diungkapkan oleh DM, sebagai masyarakat yang selalu aktif dalam dunia media sosial. Berikut adalah kutipan hasil wawancaranya:

"Facebook sangat beranfaat bagi saya terutama kita bisa engikuti berbagai macam perkembangan yang terjadi di tingkat lokal, nasional mauun internasional. Melalui media sosial ini sangat membantu juga untuk Para calon anggta legislatif yang mau maju sebagai salah satu wakil rakyat di tahun 2019 mendatang. Tahun ini sangat dikenal sebagai tahun politik. Dimana kita bisa melihat bahwa ada begitu banyak akun-akun baik yang baru di buat maupun akun yang sudah lama dibuat mulai membanjiri media Facebook. Disini sangat bagus jika ini dimanfaatkan oleh pihak terkait untuk meningkatkan jumlah pendukung terutama untuk pemilih-pemilih anak muda. Jadi para anggota legislatif tidak perlu buang-buang uang untuk menceta kartu nama, pemasangan baliho dan yang lainnya." (Wawancara, 2 Oktober 2018).

Berdasarkan hasil wawancara diatas dapat dilihat bahwa penggunaan media sosial Facebook sangat efektif untuk diterapkan oleh setiap calon anggota legislatif. Hal ini dikarenakan hampir seluruh lapisan masyarakat menggunakan mediaa Facebook pada saat ini. Selain itu, penggunaan media sosial Facebook juga sangat menghematkan biaya untuk melakukan kampanye. Hal ini terlihat bahwa untuk percetakan spanduk ataupun baliho membutuhkan biaya hingga ratusan ribu bahkan jutaan rupiah. Namun dengan pemanfaatan penggunaan media Facebook mampu memperkecil biaya untuk berkampanye dan dapat

\section{E. Penutup}

Dari uraian di atas dapat disimpulkan bahwa komunikasi politik antara para bakal calon anggota legislatif dengan para pemilihnya dapat dilakukan melalui media sosial. Media sosial sangat bermanfaat jika dapat dimanfaatkan secara efektif dan teratur oleh para penggunanya. Media sosial yang paling tepat dilakukan untuk berkomunikasi dengan Para pemilih saat ini adalah saat ini adalah media Facebook. Hal ini disebabkan karena media Facebook merupakan media sosial yang paling banyak digunakan oleh para pemilih atau masyarakat pada umumnya. Media Facebook sangatlah penting dalam kehidupan, karena dari media inilah masyarakat bisa mendapatkan informasi yang butuhkan untuk mengetahui sebuah peristiwa yang sedang terjadi saat itu juga. Karena itu media sangat berpengaruh untuk untuk memperoleh dukungan dari masyarakat. Karena kita tau bagaimana kekuatan media dalam membentuk persepsi atau opini, banyak elite politik yang menggunakan media massa untuk membentuk citra, tentu agar mendapat citra yang baik dari masyarakat.

Maka dari itu masyakat harus lebih cerdas dan lebih sadar mana elite politik yang hanya memanfaatkan media untuk pencitraan dan mana yang tulus bekerja demi rakyat tanpa menghiraukan apa yang dipikirkan publik terhadap dirinya. Maka dari itu, masyarakat harus lebih selektif dalam memilih media untuk digunakan dan mengakses informasi yang dibutuhkan jangan terlalu mudah percaya dengan apa yang disampaikan media. 


\section{Daftar Pustaka:}

Cangara, Hafied. 2009. Komunikasi Politik: Konsep, Teori dan Strategi. Jakarta: Rajawali Pers.

Chavez, Jonathan. 2012. \#Fail: The Misuse of Social Media Campaign in the 2012 US Presidential Campaign. Dapat diakses di http://www.tcd.ie/policyinstitute/assets/pdf/PL_Chavez_March12.pdf, diakses 22 Maret 2018

Effendy, Uchjana Onong. 2004. Ilmu Komunikasi Teori dan Prkatek. Bandung: PT. Remaja Rosdakarya.

Horoepoetri, Arimbi, Achmad Santosa, 2003, Peran Serta Masyarakat Dalam Pengelolaan Lingkungan, Jakarta: Walhi.

Komisi Independen Pemilihan Kabupaten Aceh Jaya, 2018

Sarwono. S. 2002. Psikologi Remaja. Jakarta: PT. Raja Grafindo

Soekanto, Soerjono, 2002, Teori Peranan, Jakarta: Bumi Aksara 